\title{
The City
}

\section{Gregory A Gould}

He said the city was so big he didn't know it had a harbour She said the city ate the sky and left her gasping for breath

He said the city stole his spirit and sold it like a dealer She said the city filled her heart with yearning and wonder

He said the city had lost its dreams under the weight of desire She said the city offered more than a person could ever want

He said the city was deceitful and full of sharp edges She said the city was filled with all kinds of art

He said the city was no place to spend a peaceful night She said the city was full of beds and people to share them with

He said a city train was no place for someone to be alone She said she wasn't alone; she said she was with him 